and sites of implantation were counted and the embryos were examined, macroscopically for a heart beat. Ovulation occured less frequently in lot $\mathrm{I}$ than in lot Io, the respective values being 56.I p. Ioo and 83.7 p. I0o in autumn, $78.3 \mathrm{p}$. Ioo and $80 \mathrm{p}$. Ioo in winter, $77.8 \mathrm{p}$. Ioo and $94.4 \mathrm{p}$. roo in spring. No significant difference was found between the two lots of rabbits for the other parameters which were examined, although values were higher for lot to than for lot $\mathbf{I}$.

The mean number of C. L. increased from autumn to spring for rabbits mated ro days after parturition, but not when the interval was one day. The percentage of early embryo survival (no. sites per no. C. L. $\times$ Ioo) was 67 p. roo in lot $\mathrm{r}$ and 77 p. Ioo in lot 10.

\title{
VARIATIONS IN THE BODY RESERVES OF FEMALE RABBITS DURING THE REPRODUCTIVE GYCLE
}

\author{
F. LEBAS \\ avec la collaboration technique de Marie-Claude Cousin, M. Theas-Laban et G. Sardi \\ Station de Recherches sur l'Elevage des Porcs, \\ Centre national de Recherches zootechniques, I. N. R. A., \\ 78350 Jouy en Josas
}

Sixty-five Californian female rabbits, having already undergone a complete reproductive cycle, were used. During pregnancy, half of the females were fed ad libitum, whereas the others only received $\mathrm{I} 4 \mathrm{O} \mathrm{g} /$ day of the same food. From parturition, all the animals were fed ad libitum, 5 of the rabbits were killed at mating and 5 rabbits per group on days ro, 2 I and 28 of gestation and on days ro, 21 and 32 after parturition. Study of the body composition of these rabbits showed a great constancy in the protein compartment of the rabbits. On the other hand, the lipid reserves of the rabbits are liable to be subjected to rapid and considerable variations. According to diets, the mobilization and deposition of lipid reserves may be recorded as well during gestation as during lactation.

\section{EFFECT OF WEIGHT AT WEANING IN THE RABBIT ON ITS SUBSEQUENT GROWTH PERFORMANCES}

\author{
F. LEBAS \\ avec la collaboration technique de Marie-Claude Cousin et G. SARDI \\ Station de Recherches sur l'Élevage des Porcs, \\ Centre national de Recherches zootechniques, I. N. R. A., \\ 78350 Jouy en Josas
}

Fourty-two litters of Californian rabbits were used for the experiment. By changing the nature and amount of diet offered before weaning ( 28 days), we obtained 2 groups of experimental animals whose weight at weaning $\left(45^{\circ} \mathrm{g}\right)$ was definitely lower than that of the control group 
$\left(55^{\circ} \mathrm{g}\right)$. The animals from these 3 treatments showed absolutely comparable growth performances between 28 and 79 days. As regards the time required to reach the same mean weight, there was a difference of $3-4 \mathrm{I} / 2$ days according to groups but in favour of the control group. Thus, a delay at weaning is not compensated (in absolute value) at the moment of slaughter.

\title{
IV. - Genetics
}

\section{REPEATABILITIES OF BREEDING PERFORMANCES AND CULLING THRESHOLDS IN FEMALE RABBITS}

\author{
R. DONAL \\ I.T.A.V.I., \\ 28, Rue du Rocher, \\ 75008 Paris
}

The variability in the numerical productivity of the doe is very high (number of rabbits weaned per doe and year). We tried to estimate levels of production under which it is economically interesting to cull a doe in a meat production farm.

The levels depend on the repeatability of the components of the numerical productivity. Repeatabilities of " interval between two parturitions " and "Iitter size at weaning " are discussed. Culling thresholds for littcr size are given. It depends on mean litter size of the flock, number of order of the litter and cost of replacement.

The results are not directly applicable if crossbreeding or " all in-all out " system is realized. If such systems are used the culling thresholds are lower. We do not consider the case of sick females which have to be culled whatever their production level.

\section{STUDY OF GENETIC VARIATION \\ IN RABBIT MUSCLE pH MEASURED AFTER SLAUGHTER}

J. OUHAYOUN*, R. ROUVIER* C. VALIN** et A. LACOURT*

avec la collaboration technique de Danièle Defmas et P. MAUrel

* Laboratoire de Méthodologie génétique,

Centre de Recherches de Toulouse, I. N.R. A., 31320 Castanet Tolosan

** Station de Recherches sur la viande,

Centre de Recherches de Clermont-Ferrand, I. N. R. A., Theix, 63110 Beaumont

The growth of 590 rabbits (4I sires and II 7 dams) was studied in the performance testing Station, Toulouse, from December 1972 to March 1973. 